\title{
PROPOLIS GATHERING ACTIVITY IN BEE COLONIES OF CARNIOLAN AND ITALIAN RACES AND THEIR HYBRIDS UNDER TEMPERATURE AND RELATIVE HUMIDITY CONDITIONS
}

Fathy, H. M. ; H. A. M. El-Fadaly ${ }^{\star *}$; E. E. A. Tharwat ${ }^{\star \star \star}$ and A. A. Tolba

"Dept. of Economic Entomol., Fac. of Agric., Mansoura Univ.

"Dept. of Microbiol., Fac. of Agric., Damietta Univ.

*** Dept. of Bee Keeping, Plant Protection Res. Inst., ARC, Giza, Egypt

\begin{abstract}
Comparative studies were carried out between Carniolan, Carniolan hybrid, Italian hybrid and Italian according to their activities in propolis gathering in a whole year under temperature and relative humidity conditions. The results showed that the highest amount of propolis in a whole year was (118.1 g/colony/year) by Carniolan hybrid colonies, while the lowest amount of propolis was $(81.5 \mathrm{~g} / \mathrm{colony} / \mathrm{year})$ by Italian hybrid colonies. The highest amounts of propolis were collected in Summer and Autumn from all races, while the lowest amount of propolis was collected during Winter season. Statistical analysis showed that highly significant differences between propolis amounts in different races. Generally, Carniolan race and its hybrid were more active in propolis gathering than Italian and its hybrid.
\end{abstract}

Keywords: Apis mellifera, Carniolan race, Italian race, propolis gathering

\section{INTRODUCTION}

Propolis is a resinous product that is gathered by honeybees from various plant exudates and is collected in beehives. With various botanical and geographical origins, more than 200 compounds have been isolated and identified from propolis (Marcucci, 1995 and Marcucci et al., 2001). The factors which trigger propolis collection by the bees are not completely understood. Some observers have suggested that seasonal factors may be responsible rather than the availability of propolis (Ashour, 1989). The world now is returning to the use of natural products both in food processing and in the field of medicine (El-Fadaly et al., 1999). Propolis is the source of the majority of the phenolic compounds present in honey. The ethanolic extract of raw propolis contains the bulk of organic constituents, which is incorporated into medicinal and health food products.

Recently, the scientist have been able to prove that propolis is as active and important as our forefathers thought. Propolis is a transformation derivate result when bees gathered or feed on tree buds, sap flows, or other botanical sources previously. So, it appears as a mixture of resins, balsams, essential oils, flavonoids, vitamins, minerals and pollen, albeit and appear in more than 300 constituents at different concentrations (Said et al., 2006; Alencar et al., 2007 and De Vecchi and Drago, 2007). 
According to qualitative and quantitative analyses, propolis shows a very rich and variable characteriation about 42 polyphenolic compounds, 13 aromatic acids, esters and alcohols, 29 flavonoids, amino acids, inorganic compounds, and 6 new compounds were identified in Egyptian propolis samples collected from different localities (Khalil, 2006 and Abd El-Hady et al., 2007). The present work aims to study the activity of bee in gathering propolis according to honeybee races in different seasons under temperature and relative humidity conditions.

\section{MATERIALS AND METHODS}

The experiments of this study were carried out at Monshaat El-Gharby, Temai-El-Amdeid, Dakahlia province for one year beginning in March 2010 and ending in February 2011.

\section{Experimental groups and propolis gathering}

For studying propolis gathering activity and its relation to brood and stored pollen amounts. Sixteen honeybee typical Langstroth hives, have (Apis mellifera L.) colonies, were chosen and divided into 4 groups (4 colonies for each) according to the race. The first group: Carniolan race, the second group: F1 Carniolan hybrid, the third group: Italian race and the fourth group: F1 Italian hybrid. All colonies were nearly similar in strength as they all were strong and contained 8 combs covered with bees and containing adequate amount of brood, honey and stored pollen. Each colony was headed by a one year old, mated and fully active egg-laying queen. Propolis was gathered every month and weighed. Collection process included scarping propolis by a sharp knife from the end of bars, the top of the frames and the inner wall hives.

\section{Determination of temperature and relative humidity:}

The study handled the effect of temperature and relative humidity on the gathering activity of propolis. The study was carried out all over a whole one year and conducted through the four seasons. The averages of temperatures and relative humidity values were continuously recorded. The records were obtained from the Bulletins of Meteorology Station, Agricultural Extension Administration, Directorate of Agriculture, Mansoura, Dakahlia Province, Ministry of Agriculture.

Statistical analysis:

The statistical analysis of the experimental data was performed using analysis of variance technique (One-Way ANOVA) and LSD (Least Significant Difference) test according to Gomez and Gomez (1984).

\section{RESULTS AND DISCUSSION}

Comparative studies were carried out between four races (Carniolan, F1 Carniolan hybrid, Italian and F1 Italian hybrid) according to their activities in propolis gathering in a whole year (2010-2011). 
The results summarized in Tables 1 \& 2 and Figs. (1, 2, 3, 4 \& 5), which indicated the activity of honeybee colonies according to different races in propolis gathering during a whole year, the amounts of collected propolis varies according to months, seasons and bee races.

Several factors are responsible in the collected amounts of porpolis. However, temperature and relative humidity play and important role in process of collecting propolis.

In the present study, the total amount of porpolis gathered by Carniolan hybrid colony was $118.1 \mathrm{~g} /$ colony/year, while the total amount of propolis gathered by Italian colony was $87.7 \mathrm{~g} /$ colony/year and Italian hybrid colony was $81.5 \mathrm{~g} /$ colony/year (Table 1 ).

In Spring, the collected amounts of propolis significantly increased per colony averaging according to bee races $25.7,20.4,17.6$ and $17.2 \mathrm{~g} /$ colony in Carniolan hybrid, Carniolan, Italian hybrid and Italian colony, respectively under temperature and relative humidity conditions $\left(18.9^{\circ} \mathrm{C} \& 61.8 \% \mathrm{RH}\right)$ as in Table 2.

The highest amount of propolis were collected in Summer and Autumn from Carniolan hybrid, Carniolan, Italian and Italian hybrid, respectively. In Summer were 38.6, 28.6, 27.2 and $24.3 \mathrm{~g} /$ colony, respectively, while in Autumn were 34.9, 33.7, 27.9 and $24.2 \mathrm{~g} /$ colony, respectively. Carniolan hybrid colonies collected amounts of propolis more than other races.

The total propolis production increased obviously in hybrid Carniolan colonies during June, July and August (Spring season) and reached to 11.97, 12.62 and $14.04 \mathrm{~g} /$ colony/month, respectively. In Autumn, the collected propolis amounts in Carniolan hybrid colonies declined to a large extent being 14.64, 21.57 and $7.78 \mathrm{~g} /$ colony/month during September, October and November, respectively. The same trend was occurred in the other races and temperature and relative humidity conditions $\left(21.5^{\circ} \mathrm{C} \& 65.3 \% \mathrm{RH}\right)$.

As indicated from Table $1 \& 2$ and Figs. 1, 2, 3, 4, \& 5, the lowest amount of propolis was collected during Winter season in colonies of different race. The average amount collected during December, January and February in Carniolan hybrid colonies were 5.69, 5.08 and $8.16 \mathrm{~g} /$ colony/month, respectively. In Winter, Italian, Italian hybrid and Carniolan, the total amount of propolis gathered were $18.9,15.4,15.4$ and $13.8 \mathrm{~g} /$ colony, respectively under temperature and relative humidity conditions $\left(16.1^{\circ} \mathrm{C} \& 70.1 \% \mathrm{RH}\right)$.

Therefore, porpolis production was highly produced during warm seasons specially in Summer since temperature ranged between 26.2 to $28.2^{\circ} \mathrm{C}$ and relative humidity ranged between $59.5 \%$ to $67.5 \% \mathrm{RH}$.

From the data presented in Table 2, it could be seen that the production of propolis per colony according to bee races during a year ranged between 118.1, 96.5, 87.7 and $81.5 \mathrm{~g} /$ colony/year in Carniolan hybrid, Carniolan, Italian and Italian hybrid colonies, respectively.

Statistical analysis showed that the differences as in between season and bee races as in table 3 , showed highly significant differences between propolis amounts indifferent races. It was not found significant differences between propolis amounts in Summer and Autumn in all bee races, while it 
was found significant differences between propolis amounts. In Autumn, and Winter in all bee races (Table 3 ).

The results showed that Carniolan hybrid bees collected propolis more active than other races, which means that Carniolan hybrid colonies gather $30.77 \%$ from the total amounts of propolis more than Carniolan colonies (25.14\%), Italian colonies (22.85\%) and Italian hybrid colonies (21.24\%).

Table 1. Monthly average and percentage production of propolis (g/colony) according to honeybee race under different temperatures and relative humidity conditions during a whole year (2010-2011).

\begin{tabular}{|c|c|c|c|c|c|c|}
\hline \multirow{2}{*}{ Month } & \multirow{2}{*}{$\begin{array}{c}\text { Mean of } \\
\text { Temp. }\end{array}$} & \multirow{2}{*}{$\begin{array}{c}\text { Mean of } \\
\text { RH\% }\end{array}$} & \multicolumn{4}{|c|}{ g propolis/colony } \\
\hline & & & I & $\mathrm{IH}$ & $\mathrm{CH}$ & $\mathbf{C}$ \\
\hline Mar. & 14.67 & 59.51 & 5.065 & 5.04 & 8.005 & 6.27 \\
\hline Apr. & 20.70 & 64.03 & 5.725 & 6.065 & 8.82 & 6.47 \\
\hline May & 21.48 & 61.93 & 6.435 & 6.505 & 8.9 & 7.645 \\
\hline Jun. & 26.17 & 59.53 & 7.83 & 7.06 & 11.975 & 8.685 \\
\hline Jul. & 27.84 & 65.67 & 9.585 & 8.14 & 12.615 & 8.755 \\
\hline Aug. & 28.22 & 67.48 & 9.765 & 9.105 & 14.04 & 11.11 \\
\hline Sep. & 24.38 & 64.36 & 10.79 & 10.04 & 14.64 & 12.84 \\
\hline Oct. & 22.48 & 63.06 & 9.05 & 8.06 & 12.57 & 12.325 \\
\hline Nov. & 17.65 & 68.36 & 8.075 & 6.135 & 7.78 & 8.555 \\
\hline Dec. & 15.74 & 69.16 & 5.5 & 5.06 & 5.69 & 4.18 \\
\hline Jan. & 15.47 & 71.48 & 4.92 & 6.345 & 5.085 & 3.57 \\
\hline Feb. & 17.00 & 69.60 & 4.99 & 4.0 & 8.16 & 6.04 \\
\hline Total & & & 87.73 & 81.56 & 118.28 & 96.45 \\
\hline
\end{tabular}

$\mathrm{I}=$ Italian race $\quad \mathrm{IH}=$ Italian hybrid race

$\mathrm{C}=$ Carniolan race $\mathrm{CH}=$ Carniolan hybrid race

Table 2. Seasonal average and percentage production of propolis (g/colony) according to honeybee race under different temperatures and relative humidity conditions during a whole year (2010-2011).

\begin{tabular}{|c|c|c|c|c|c|c|}
\hline \multirow{2}{*}{ Season } & \multirow{2}{*}{$\begin{array}{l}\text { Mean of } \\
\text { Temp. }\end{array}$} & \multirow{2}{*}{$\begin{array}{c}\text { Mean of } \\
\text { RH\% }\end{array}$} & \multicolumn{4}{|c|}{ g propolis/colony } \\
\hline & & & I & IH & $\mathrm{CH}$ & $\mathbf{C}$ \\
\hline Spring & 18.9 & 61.80 & 17.2 & 17.6 & 25.7 & 20.4 \\
\hline Summer & 27.4 & 64.20 & 27.2 & 24.3 & 38.6 & 28.6 \\
\hline Autumn & 21.5 & 65.26 & 27.9 & 24.2 & 34.9 & 33.7 \\
\hline Winter & 16.1 & 70.08 & 15.4 & 15.4 & 18.9 & 13.8 \\
\hline Total & 383.8 & & 87.7 & 81.5 & 118.1 & 96.5 \\
\hline Percentage (\%) & $100 \%$ & & $22.85 \%$ & $21.24 \%$ & $30.77 \%$ & $25.14 \%$ \\
\hline
\end{tabular}

I = Italian race $\quad \mathrm{IH}=$ Italian hybrid race

$\mathrm{C}=$ Carniolan race $\quad \mathrm{CH}=$ Carniolan hybrid race

Table 3. Analysis of variance of average amounts of propolis (g/colony) in different seasons collected from different bee races (L.S.D. at 0.05)

\begin{tabular}{|c|c|c|c|c|}
\hline Season & Carniolan & Carniolan hybrid & Italian & Italian hybrid \\
\hline Spring & $20.4 \mathrm{a}$ & $25.7 \mathrm{a}$ & $17.2 \mathrm{a}$ & $17.6 \mathrm{a}$ \\
\hline Summer & $20.6 \mathrm{~b}$ & $38.6 \mathrm{~b}$ & $27.2 \mathrm{~b}$ & $24.3 \mathrm{~b}$ \\
\hline Autumn & $33.7 \mathrm{c}$ & $34.9 \mathrm{~b}$ & $27.9 \mathrm{~b}$ & $24.2 \mathrm{~b}$ \\
\hline Winter & $13.8 \mathrm{c}$ & $18.9 \mathrm{c}$ & $15.4 \mathrm{a}$ & $15.4 \mathrm{a}$ \\
\hline Total & 96.5 & 118.1 & $\mathbf{8 7 . 7}$ & $\mathbf{8 1 . 5}$ \\
\hline
\end{tabular}

There are insignificant differences between the means with the same letters 


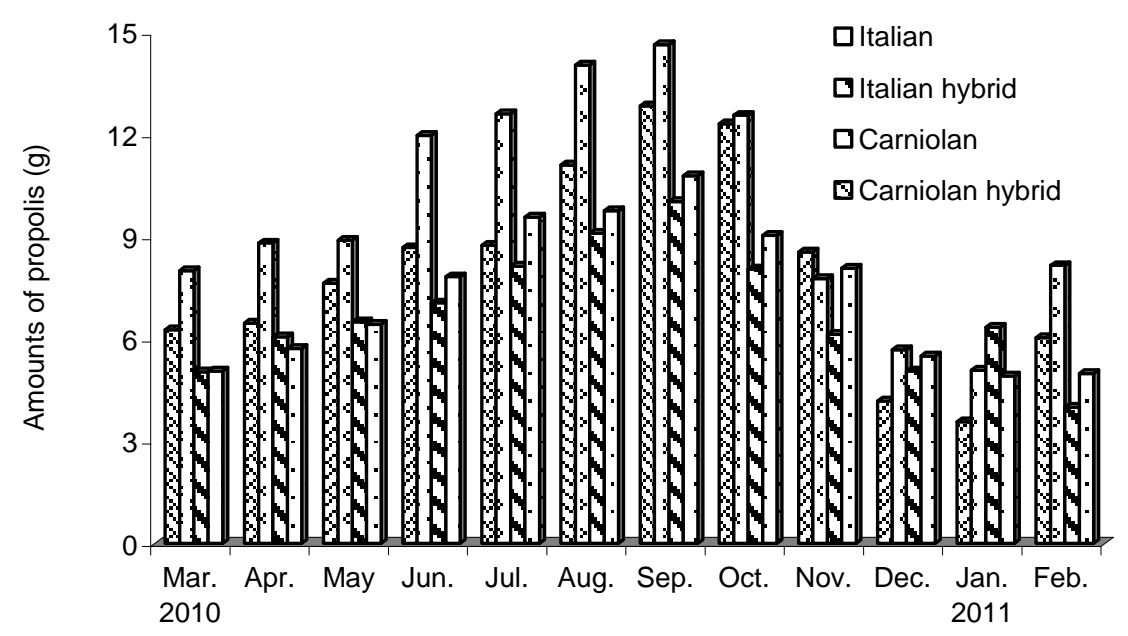

Fig. 1. Activity of propolis gathering by the different honeybee races during a whole year.
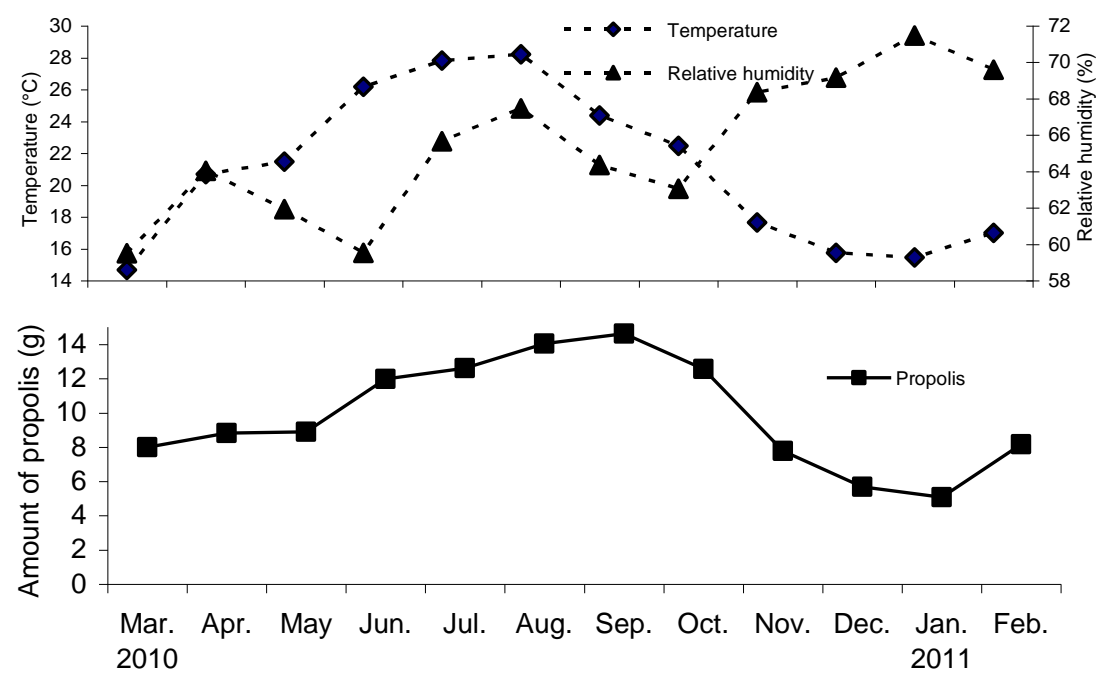

Fig. 2. Activity of propolis gathering by Carniolan hybrid race under different temperatures $\left({ }^{\circ} \mathrm{C}\right)$ and relative humidity $(\mathrm{RH} \%)$ in a whole year. 

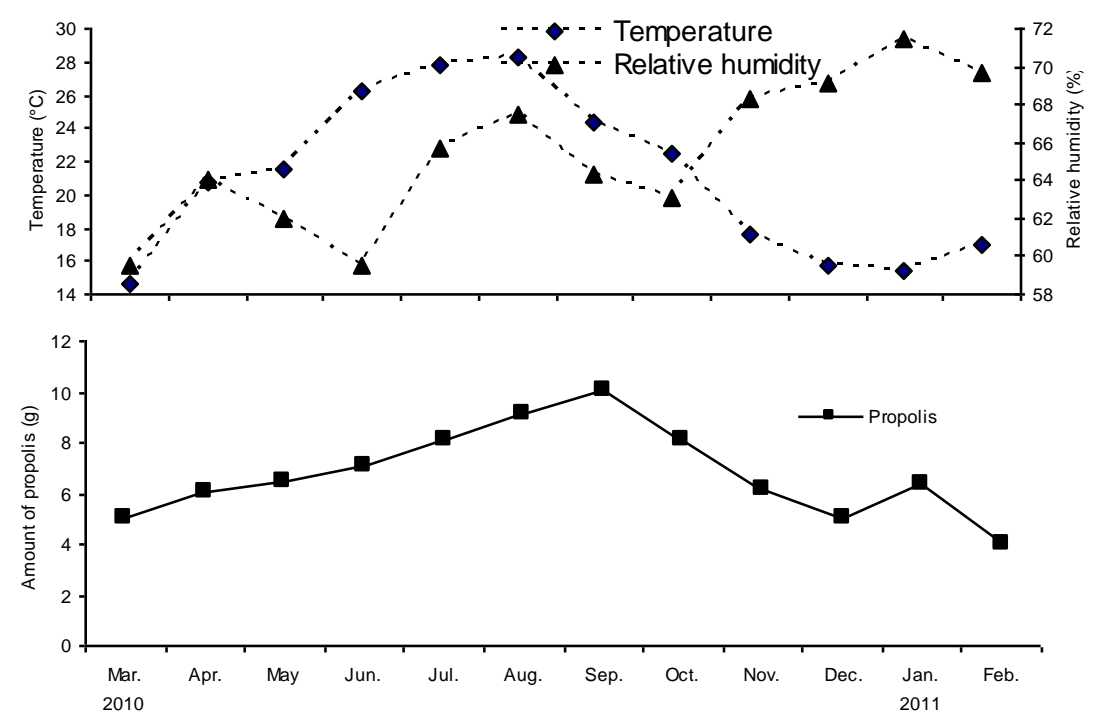

Fig. 3. Activity of propolis gathering by Italian hybrid race under different temperatures $\left({ }^{\circ} \mathrm{C}\right)$ and relative humidity $(\mathrm{RH} \%)$ in a whole year.
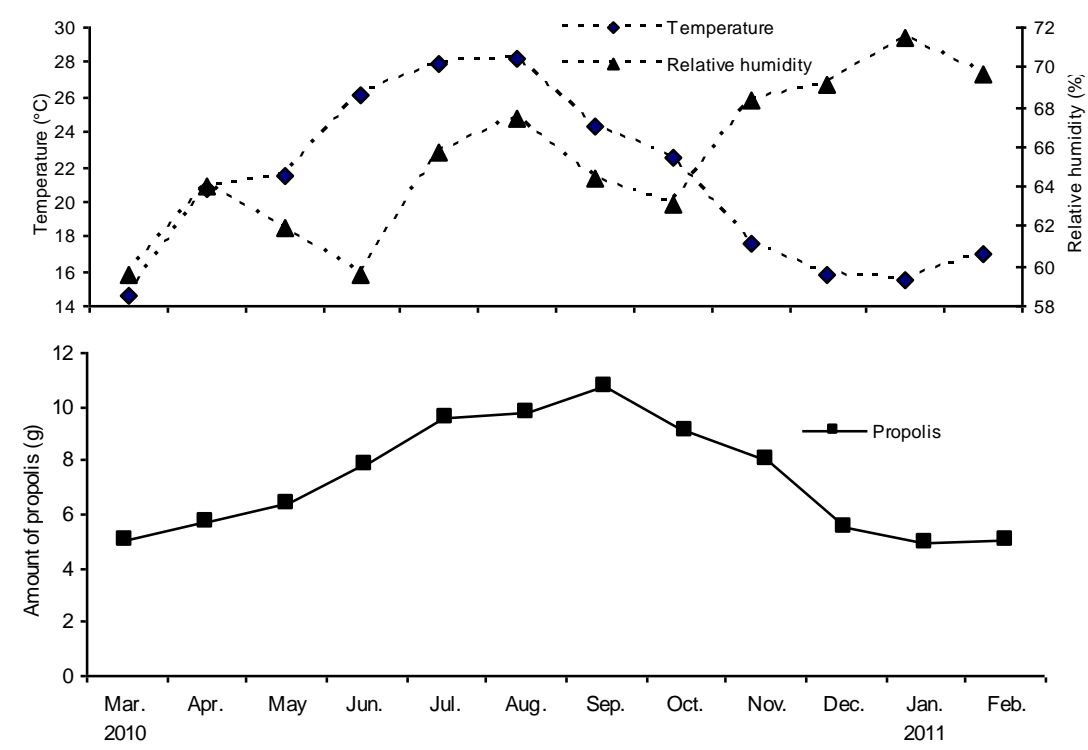

Fig. 4. Activity of propolis gathering by Italian race under different temperatures $\left({ }^{\circ} \mathrm{C}\right)$ and relative humidity $(\mathrm{RH} \%)$ in a whole year. 

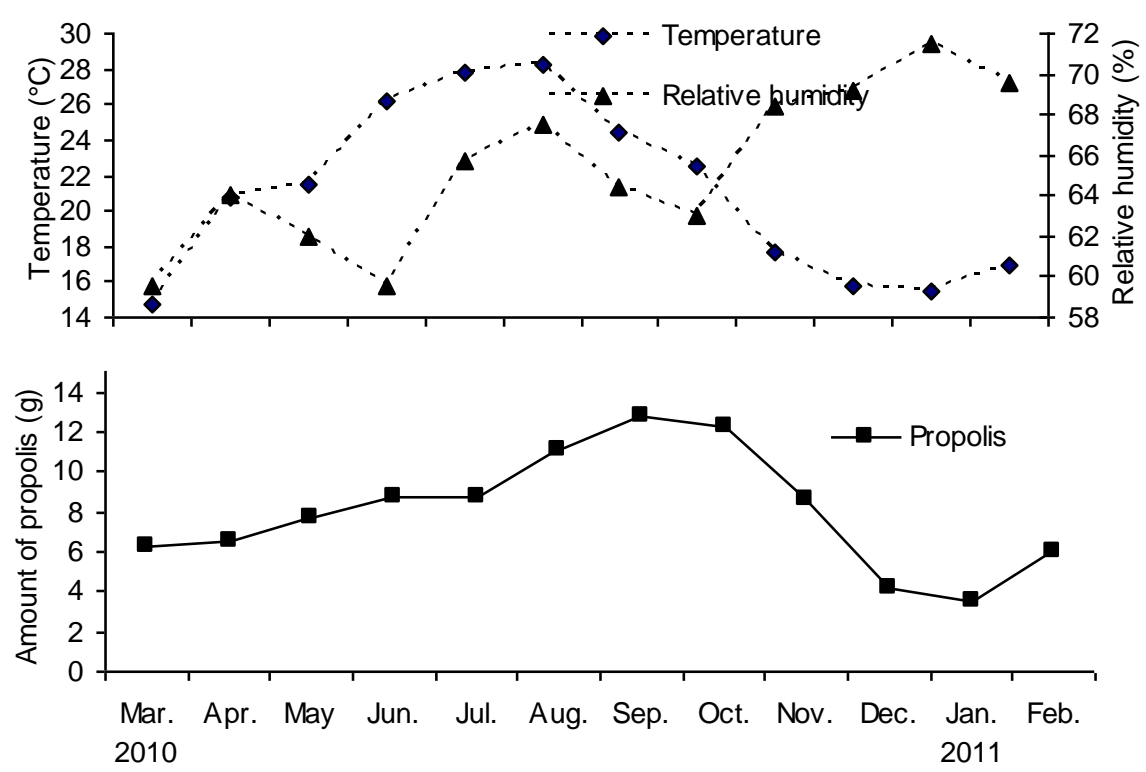

Fig. 5. Activity of propolis gathering by Carniolan race under different temperatures $\left({ }^{\circ} \mathrm{C}\right)$ and relative humidity $(\mathrm{RH} \%)$ in a whole year.

These results are in agreement with (Starostensko, 1968; Krupicka, 1972 and Taha, 2006). They reported that some races of honeybee collected propolis more active than others. Also, these results are in accordance with those of (Ashour, 1989; El-Shaarawy, 1989 and Ghazala, 1989). They reported that $\mathrm{F} 1$ Carniolan hybrid was collecting more quantities of porpolis than Carniolan race.

Generally, Carniolan race and its hybrid were more active in propolis gathering than Italian race and its hybrid and this may due to the that Carniolan race is more suitable to collect propolis in Egypt than Italian race.

\section{REFERENCES}

Abd El-Hady, F. K.; Hegazi, A. G. and Wollenweber, E. (2007). Effect of Egyptian propolis on the susceptibility of LDL to oxidative modification and its antiviral activity with special emphasis on chemical composition. Z. Naturforsch., 62(9-10): 645-655.

Alencar, S. M.; Oldoni, T. L. C.; Castro, M. L.; Cabral, I. S. R.; Costa-Neto, C. M.; Cury, J. A.; Rosalen, P. L. and Ikegaki, M. (2007). Chemical composition and biological activity of a new type of Brazilian propolis: Red propolis. J. Ethnopharmacol., 113: 278-283. 
Ashour, A. T. (1989). Studies on propolis gathering with special reference to its antimicrobial properties. M. Sc. Thesis, Fac. of Agric. Cairo Univ., Cairo, Egypt.

De Vecchi, E. and Drago, L. (2007). Propolis' antimicrobial activity: what is new? Infez. Med., 15(1): 7-15.

El-Fadaly, H.; Hassan, B. and El-Badrawy, E. E. (1999). Antifungal potentialities of some plant extracts compared to some yeasts and bacteria. Proc. The 2nd Int. Conf. Fungi: Hopes \& Challenges, Cairo, 29th Sept - 1st Oct., Vol. II, pp. 95-108.

El-Shaarawy, M. O. (1989). The effect of feeding honeybee colonies by pollen substitutes on worker brood rearing and citrus honey J. Agric. Sci. Mansoura univ., 26(6): 3683-3987.

Ghazala, N. A. (1998). Studies on propolis production. M. Sc. Thesis, Fac. of Agric. At Moshtohor Zagazig Univ.,132pp.

Khalil, M. L. (2006). Biological activity of bee propolis in health and disease. Asian Pac. J. Cancer Prev., 7: 22-31.

Krupicka, P. (1972). Methods of obtaining propolis. Inter symp. of propolis. Bbratilava. Nov. 1972.

Marcucci, M. C. (1995). Propolis: chemical composition, biological properties and therapeutic activity. Apidologie, 26: 83-99.

Marcucci, M.; Ferrres, F.; Garcia-Viguera, C.; Bankova, V.; De Castro, S.; Dantas, A.; Valente, P. and Paulino, N. (2001). Phenolic compounds from brazilian propolis with pharmacological activities. J. Ethanoph., 74: 105-112.

Said, S. A.; Khan, S. A.; Ahmad, I. and Ali, H. S. (2006). Chemical composition of Egyptian and UAE Propolis. Pak. J. Pharm. Sci., 19(1): 58-61.

Starostensko E. V. (1968). Propolization by bees of various races. Pchelovodstvo 88(7): 30.

Taha, A. A. (2006). Comparative studies on some secondary products in different races. Ph. D. Thesis, Fac. of Agric. Mansoura Univ., Egypt.

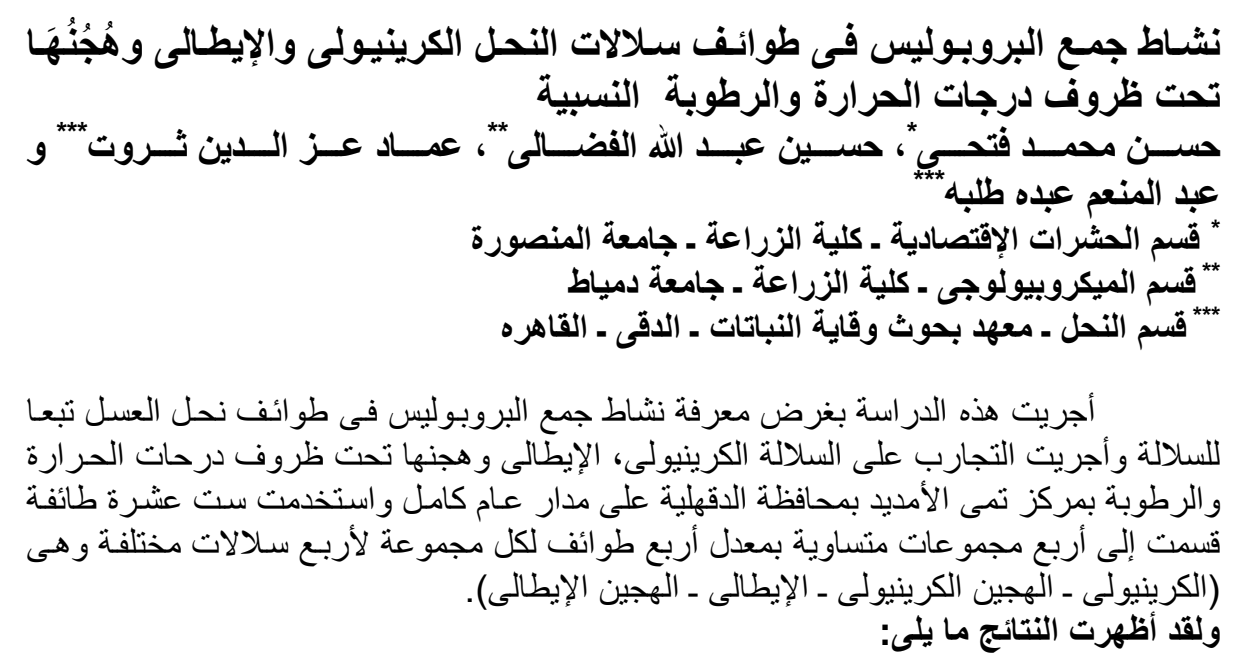


أو لاً: أعلى كمية من البروبوليس جمعت على مدار العام كان من طو ائف الهجين الكرينيولى لئى

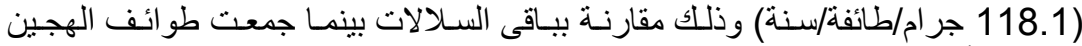

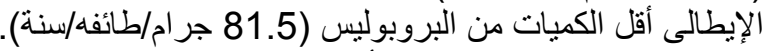

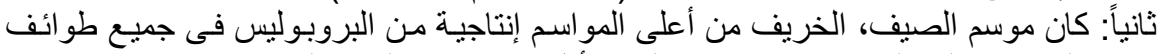

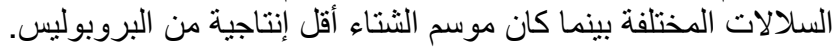

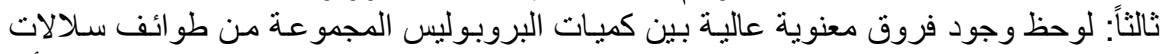

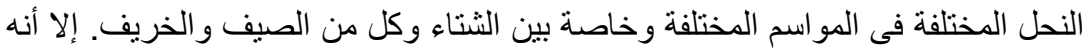

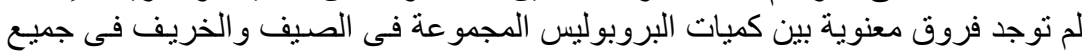
طو ائف السلالات الدختلفة.

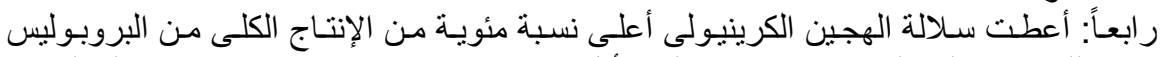

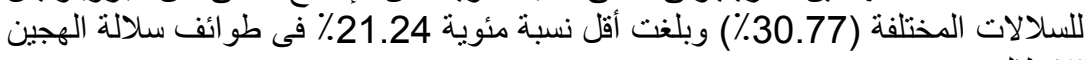

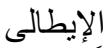

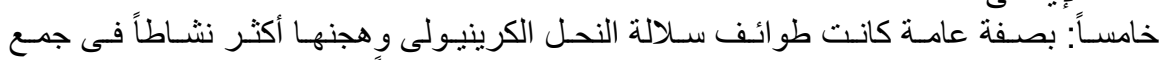

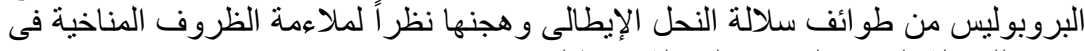
مصر اللسلالة الكرينيولى عن السلالة الإيطالى.

كلية الزراعة - جامعة المنصورة كلية الزراعة - جامعة الاسكندريه
قام بتحكيم البحث

أ. أد / سمير صالح عوض البد الله

أ.د / اسـامه محمد الاتصارى صوض الذ 